specimens were taken. Obviously, however, the morphological changes are not reflected by changes in function as judged by glomerular filtration rate and renal plasma flow.

The high level of kidney function generally found in diabetics without proteinuria should be considered when evaluating results in proteinuric diabetics. Thus values in the lower normal range might be abnormal for diabetics, since they should be compared with the higher level in non-proteinuric diabetics.

It is perhaps surprising that an increased glomerular filtration rate has not been reported previously in long-term diabetics without proteinuria. Of course, initially patients with clinically obvious nephropathy were investigated, and here decreased glomerular filtration rate and renal plasma flow are major findings (Corcoran et al., 1948; Rotertson et al., 1951; Brun et al., 1953; Lundbaek, 1953; Bucht et al., 1956; Latotzki, 1958; Thomsen, 1965; Lüdtke, 1966). In the present study welldefined comparable groups were examined, the mean ages of the long-term diabetics and normal subjects being 28 and 25 years respectively. The present studies were thus confined to young subjects; hence the possible influence of age-dependent vascular disease is minimized.

Early changes in kidney function may be important in the development of diabetic nephropathy (Stalder et al., 1960; Ditzel and Junker, 1972), and increased permeability and possibly increased filtration pressure might lead to degenerative changes in the glomerulus. At the present time this important question is not fully clarified. Nevertheless, the increased glomerular filtration rate of early diabetes is associated with normal permeability to large molecular dextran molecules (Mogensen, 1971a). Furthermore, normal urinary albumin excretion has been found in most juvenile diabetics without proteinuria irrespective of the duration of diabetes, and this also suggests normal glomerular permeability to macromolecules (Mogensen, 1971e).

The present study showed that increased glomerular filtration rate and increased filtration fraction can be found in diabetics of very long duration. The glomerular filtration rate and the filtration fraction have probably been at the same high level for many years without causing clinical nephropathy. Radiological studies in short-term juvenile diabetics with increased glomerular filtration rates have shown that the kidney is enlarged (Mogensen and Andersen, 1972). These findings suggest that increased kidney size is important in the high glomerular filtration rate of early diabetes. The increased rate does not necessarily reflect vascular changes in the glomerular capillary wall.
In my opinion these findings speak against the concept that the abnormalities in kidney function play a major part in the development of the morphological alterations of the diabetic nephropathy.

My thanks are due to Mrs. Bodil Willumsen for her sikilful technical help. The investigations were supported by grants from Statens laegevidenskabelige Forskningsråd, Denmark.

\section{References}

Brun, C., Gormsen, H., Hilden, T., Iversen, P., and Raaschou, F. (1953). American fournal of Medicine, $15,187$.

Bucht, H., Ek, J., and Werkö, L. (1956). Scandinavian Fournal of Clinical and Laboratory Investigation, 8, 309.

Christensen, N. J. (1967). Scandinavian fournal of Clinical and Laboratory Investigation, 19, 379.

Corcoran, A. C., Taylor, R. D., and Page, I. H. (1948). Annals of Internal Medicine, 28, 560 .

Deckert, T., and Poulsen, J. E. (1968). Acta Medica Scandinavica, 183, 351.

Ditzel, J., and Junker, K. (1972). British Medical fournal, 2, 13.

Ditzel, J., and Schwartz, M. (1967). Diabetes, 16, 264.

Elwood, C. M., and Sigman, E. M. (1967). Circulation, 36, 441.

Elwood, C. M., and Sigman, E. M. (1967). Circulation, 36, 441. Radiology, 40, 581 .

Jensen, V. A., and Lundbaek, K. (1971). In Handbuch des Diabetes Mellitus, ed. E. F. Pfeiffer, vol. 2, p. 659. Munich, Lehmanns.

Latotzki, H. (1958). Zeitschrift für klinische Medizin, 155, 158.

Lazarow, A. (1969). Proceedings of the Sixth Congress of the International Diabetes Federation, 1967, ed. J. Östman, p. 301. Amsterdam, Excerpta Medica.

Ludtke, E. (1966). Zeitschrift für innere Medizin, 21, 134.

Lundbaek, K. (1953). Long-term Diabetes. Copenhagen, Munksgaard.

Lundbaek, K. (1965). In On the Nature and Treatment of Diabetes, ed. B. S. Leibel and G. A. Wrenshall, p. 436. Amsterdam, Excerpta Medica.

Magnusson, G. (1962). Acta Medica Scandinavica, 117, Suppl., 378.

Mogensen, C. E. (1971a). Scandinavian Fournal of Clinical and Laboratory Investigation, 28, 79.

Mogensen, C. E. (1971b). Scandinavian Fournal of Clinical and Laboratory Investigation, 28, 91 .

Mogensen, C. E. (1971c). Scandinavian fournal of Clinical and Laboratory Investigation, 28, 101 .

Mogensen, C. E. (1971d). Scandinavian Fournal of Clinical and Laboratory Investigation, 28, 177 .

Mogensen, C. E. (1971e). Scandinavian Fournal of Clinical and Laboratory Investigation, 28, 183

Mogensen, C. E. (1972). Danish Medical Bulletin, 19, Suppl., 3.

Mogensen, C. E., and Friis Andersen, M. J. (1972). To be published.

Osterby, R. (1971). In Microcirculatory Approaches to Current Therapeutic Problems, eds. J. Ditzel and D. H. Lewis. Basel, Karger.

Østerby, R. (1972). Diabetologia., 8, 84.

Robertson, J. A., Gray, C. H., and Banes, A. H. (1951). Archives of Internal Medicine, 87,570 .

Skov, P. E. (1970). Acta Medica Scandinavica, 187, 419.

Stalder, G., Schmid, R., and Wolff, M. V. (1960). Deutsche medizinische Wochenschrift, 85, 346.

Summers, R. E., Concannon, J. P., Weil, C., and Cole, C. (1967). Fournal of Laboratory and Clinical Medicine, 69, 919.

Thomsen, Aa. Chr. (1965). The Kidney in Diabetes. Copenhagen, Munksgaard.

\title{
Idiopathic Palsy of the Recurrent Laryngeal Nerve: A Transient Cranial Mononeuropathy
}

\author{
J. N. BLAU, RUMY KAPADIA
}

British Medical fournal, 1972, 4, 259-261

no major disease during the subsequent one to eight years.

\section{Summary}

Unilateral vocal cord palsy can be a benign condition with a reasonable chance of spontaneous recovery. Analysis of 21 selected patients has shown that 5 recovered completely and another 5 improved within months of the onset. The remaining 11 patients developed

National Hospital, Queen Square, London W.C.1

J. N. BLAU, M.D., F.R.C.P., Consultant Physician

Royal National Throat, Nose and Ear Hospital, London W.C.1 R. KAPADIA, F.R.c.s., Senior Registrar

\section{Introduction}

Foley (1969) coined the elegant term "the cranial mononeuropathies" in a leading article on transient cranial nerve palsies and cited the 3rd, 5th, 6th, 7th, 8th, and 12th nerves. Although idiopathic palsy of the recurrent laryngeal nerve is well recognized by laryngologists the proportion of patients who recover is less widely appreciated. In spite of negative investigations these patients are often suspected of harbouring mediastinal malignancy by the E.N.T. surgeon or the general physician or neurologist who may be consulted. 
Idiopathic palsies of the recurrent laryngeal nerve with recovery have been reported (for review see Williams, 1959), usually in specialist journals. For this reason and to support the concept of the cranial mononeuropathies we draw attention to this palsy, which in some instances is benign and then has a fair chance of recovery.

\section{Present Series}

Patients were referred by general practitioners to surgeons at the Royal National Throat, Nose and Ear Hospitals, Grays Inn Road or Golden Square. Each patient was examined by indirect laryngoscopy and had a chest $x$-ray examination, estimation of the blood sedimentation rate, and a blood V.D.R.L. test. Some were admitted for endoscopy under general anaesthesia; the examination included direct laryngoscopy, bronchoscopy, and oesophagoscopy. Five patients also had a barium-swallow examination. Cases in which a primary disease was found or with bilateral vocal cord palsy were excluded, leaving 21 in this series.

All patients were asked to attend for re-examination from a general medical, neurological, and E.N.T. point of view, the latter including indirect layrngoscopy. We excluded a further 15 patients -7 with full recovery and 8 without recovery-who declined to attend again or who could not be traced.

The salient clinical features of the 21 patients are summarized in Tables I-III. The initial hospital attendance was usually within four to eight weeks of the voice becoming hoarse-the only symptom in 19 patients; two also complained of a sore throat, and one of these had transient dysphagia. Age or the side affected seemed not to influence the prognosis. The predominance of males in the complete and partial recovery group was probably a matter of chance.

Return of vocal cord movement was seen at the earliest two months after the onset of hoarseness, and no recovery occurred after nine months. Of the five instances where the cord remained paralysed two patients thought that their voices had returned to

TABLE I-Patients Showing Complete Recovery

\begin{tabular}{|c|c|c|c|c|c|c|}
\hline $\begin{array}{l}\text { Case } \\
\text { No. }\end{array}$ & $\begin{array}{l}\text { Sex } \\
\text { and } \\
\text { Age }\end{array}$ & $\begin{array}{l}\text { Side } \\
\text { of } \\
\text { Palsy }\end{array}$ & $\begin{array}{l}\text { Duration of } \\
\text { Symptoms Before } \\
\text { First Seen }\end{array}$ & $\begin{array}{l}\text { Partial } \\
\text { Recovery } \\
\text { Noted }\end{array}$ & $\begin{array}{l}\text { Full } \\
\text { Recovery } \\
\text { Noted }\end{array}$ & $\begin{array}{l}\text { Follow- } \\
\text { up } \\
\text { Period }\end{array}$ \\
\hline $\begin{array}{l}1 \\
2 \\
3 \\
4 \\
5\end{array}$ & $\begin{array}{l}\text { M. } 54 \\
\text { M. } 45 \\
\text { M. } 25 \\
\text { M. } 40 \\
\text { M. } 31\end{array}$ & $\begin{array}{l}\text { L. } \\
\text { L. } \\
\text { L. } \\
\text { R. }\end{array}$ & $\begin{array}{r}4 \text { weeks } \\
4 \text { weeks } \\
3 \text { weeks } \\
12 \text { weeks } \\
5 \text { weeks }\end{array}$ & $\begin{array}{l}2 \text { months } \\
\text { No } \\
\text { No } \\
4 \text { months } \\
\text { No }\end{array}$ & $\begin{array}{l}5 \text { months } \\
7 \text { months } \\
3 \text { months } \\
6 \text { months } \\
3 \text { months }\end{array}$ & $\begin{array}{l}7 \text { years } \\
6 \text { years } \\
1 \text { year } \\
9 \text { months } \\
3 \text { months }\end{array}$ \\
\hline
\end{tabular}

TABLE II-Patients Showing Incomplete Recovery

\begin{tabular}{|c|c|c|c|c|c|}
\hline $\begin{array}{l}\text { Case } \\
\text { No. }\end{array}$ & $\begin{array}{l}\text { Sex } \\
\text { and } \\
\text { Age }\end{array}$ & $\begin{array}{l}\text { Side } \\
\text { of } \\
\text { Palsy }\end{array}$ & $\begin{array}{c}\text { Duration of } \\
\text { Symptoms Before } \\
\text { First Seen }\end{array}$ & $\begin{array}{c}\text { Partial } \\
\text { Recovery } \\
\text { Noted }\end{array}$ & $\begin{array}{c}\text { Follow-up } \\
\text { Period }\end{array}$ \\
\hline $\begin{array}{r}6 \\
7 \\
8 \\
9 \\
10\end{array}$ & $\begin{array}{l}\text { M. } 42 \\
\text { M. } 28 \\
\text { F. } 63 \\
\text { M. } 29 \\
\text { M. } 40\end{array}$ & $\begin{array}{l}\text { L. } \\
\text { R. } \\
\text { L. } \\
\text { L. } \\
\text { L. }\end{array}$ & $\begin{array}{l}5 \text { weeks } \\
4 \text { weeks } \\
8 \text { weeks } \\
2 \frac{1}{2} \text { weeks } \\
5 \text { weeks }\end{array}$ & $\begin{array}{l}6 \text { months } \\
8 \text { months } \\
8 \text { months } \\
9 \text { months } \\
3 \text { months }\end{array}$ & $\begin{array}{l}5 \text { years } \\
3 \text { years } \\
1 \frac{1}{2} \text { years } \\
1 \frac{1}{\text { years }} \\
1 \frac{1}{2} \text { years }\end{array}$ \\
\hline
\end{tabular}

TABLE III-Patients Showing No Recovery

\begin{tabular}{|c|c|c|c|c|}
\hline $\begin{array}{l}\text { Case } \\
\text { No. }\end{array}$ & $\begin{array}{l}\text { Sex } \\
\text { and } \\
\text { Age }\end{array}$ & $\begin{array}{c}\text { Side } \\
\text { of } \\
\text { Palsy }\end{array}$ & $\begin{array}{l}\text { Duration of Symptoms } \\
\text { Before First Seen }\end{array}$ & Follow-up Period \\
\hline $\begin{array}{l}11 \\
12 \\
13 \\
14 \\
15 \\
16 \\
17 \\
18 \\
19 \\
20 \\
21\end{array}$ & $\begin{array}{l}\text { M. } 18 \\
\text { M. } 19 \\
\text { F. } 40 \\
\text { F. } 54 \\
\text { M. } 25 \\
\text { F. } 53 \\
\text { F. } 42 \\
\text { F. } 52 \\
\text { M. } 59 \\
\text { M. } 61 \\
\text { M. } 51\end{array}$ & $\begin{array}{l}\text { L. } \\
\text { L. } \\
\text { L. } \\
\text { R. } \\
\text { R. } \\
\text { L. } \\
\text { L. } \\
\text { R. } \\
\text { L. } \\
\text { L. }\end{array}$ & $\begin{array}{c}6 \text { years } \\
5 \text { years } \\
26 \text { weeks } \\
8 \text { weeks } \\
16 \text { weeks } \\
14 \text { months } \\
1 \text { year } \\
\text { Incidental discovery } \\
16 \text { weeks } \\
3 \text { weeks } \\
3 \text { weeks }\end{array}$ & $\begin{array}{l}8 \text { years } \\
6 \frac{1}{2} \text { years } \\
5 \frac{1}{2} \text { years } \\
41 \text { years } \\
31 \text { years } \\
3 \frac{1}{2} \text { years } \\
3 \text { years } \\
2 \text { years } \\
1 \text { year } \\
1 \text { year } \\
1 \text { year }\end{array}$ \\
\hline
\end{tabular}

normal, but examination showed that the opposite cord had compensated adequately for normal speech.

Treatment.-In two instances of permanent palsy the paralysed cord was injected with Teflon (polytetrafluoroethylene), with noticeable improvement in phonation in one and a moderate degree of improvement in the other.

\section{Discussion}

The longest interval between onset and recovery of the vocal cord palsy was nine months, which agrees with other series (Huppler, Schmidt, Devine, and Gage, 1956; Williams, 1959). Hence up to this time an optimistic prognosis can be entertained. It also suggests that injection of the vocal cord to improve phonation should not be undertaken before a full year has elapsed. In many cases this procedure is unnecessary because compensatory movement of the opposite cord will often result in a normal speaking voice.

Patients attended hospital only when they had been hoarse for several weeks. Patients with quicker recovery may not visit their own family practitioner, because hoarseness is often attributed to an upper respiratory infection. Hence the proportion of patients who recover may be underestimated.

A previous communication described a transient trigeminal sensory neuropathy (Blau, Harris, and Kennet, 1969), and evidence was cited in favour of a transient abducens palsy in children (Knox, Clark, and Schuster, 1967) as well as in the elderly. The benign character of the more common Bell's palsy, as well as the disturbances affecting either portion of the eighth cranial nerve, lends further support to the concept of "the cranial mononeuropathies" as a disease entity.

A definitive pathogenetic mechanism is nevertheless lacking. The common associations of isolated cranial nerve palsies, especially of the third and sixth nerves, are diabetes and atherosclerosis, when it is currently assumed that the nerve trunks have been infarcted. However, the following evidence shows that in some instances an infective process, possibly viral, may produce a variety of cranial nerve lesions. (1) Zoster affects the fifth and seventh cranial nerves. (2) Upper respiratory infections due to influenza $A$ and other viruses can give rise to multiple cranial nerve palsies, including ophthalmoplegia, bilateral facial weakness, or dysphagia with paralysis of the soft palate and vocal cords (Wells, 1971). (3) Vaccination may result in a superior rectus or abducens palsy unilaterally or bilateral facial weakness (Spillane and Wells, 1964). (4) A rise in mumps antibody titre occurs in a proportion of patients with sudden unilateral deafness or Bell's palsy (Saunders and Lippy, 1959). (5) In a large series of Bell's palsy a seasonal incidence was apparent (El-Ebiary, 1971). Furthermore, outbreaks of upper respiratory infections may be associated with vertigo of benign nature (Pedersen, 1959).

\section{Conclusion}

We conclude that it is reasonable to accept the entity of the cranial mononeuropathies-a benign condition in which individual cranial nerves are palsied, partially or totally. The site of involvement in the neural axis is undetermined and the likelihood of recovery varies with the individual nerve.

With recent advances in virology the time seems ripe to incriminate or dismiss a viral cause for transient cranial nerve lesions. It would clearly be sensible to tackle the aetiology of Bell's palsy because it is the most common of these neuropathies and because patients seek attention at an early stage of the illness.

We are grateful to the consulting surgeons of the Royal National Throat, Nose and Ear Hospitals, who allowed us to see patients under their care, and to Mr. Maxwell Ellis, Mr. Spencer Harrison, and Mr. Ellis Douek for helpful discussion. 


\section{References}

Blau, J. N., Harris, M., and Kennett, S. (1969). New England fournal of Medicine, 281, 873.

El-Ebiary, H. M. (1971). Rheumatology and Physical Medicine, 11, 100

Foley, J. M. (1969). New England fournal of Medicine, 281, 905.

Huppler, E. G., Schmidt, H. W., Devine, K. D., and Gage, R. P. (1956). American Review of Tuberculosis, 73, 52 .
Knox, D. L., Clark, D. B., and Schuster, F. F. (1967). Pediatrics, 40, 560. Pedersen, E. (1959). Brain, 82, 566.

Saunders, W. H., and Lippy, W. H. (1959). Annals of Otology, Rhinology and Laryngology, 68, 830 .

and Laryngology, 68, 830. . . (1964). Brain, 87, 1.

Wells, C. E. C. (1971). British Medical fournal, 1, 369

Williams, R. G. (1959). Fournal of Laryngology and Otology, 73, 161.

\title{
Lymphocyte Sensitization to Carcinoembryonic Antigen (Gold) with Special Reference to Multiple Sclerosis
}

\author{
E. J. FIELD, E. A. CASPARY
}

British Medical fournal, 1972, 4, 261-263

\begin{abstract}
Summary
Lymphocytes from patients with multiple sclerosis are sensitized to carcinoembryonic antigen (C.E.A.) in almost the same degree as are those from subjects with cancer. During pregnancy and the early puerperium there is an even higher degree of cellular sensitization to C.E.A. Patients with neurological diseases other than multiple sclerosis also show significant sensitization to C.E.A. though of less degree than do those with multiple sclerosis. Sensitization to C.E.A. is thus not specifically characteristic of cancer. The unexpected sensitization in multiple sclerosis may be associated with the pronounced degree of gliosis found in that condition.
\end{abstract}

\section{Introduction}

Lymphocytes from patients with malignant neoplasia are sensitized to encephalitogenic factor (E.F.)-a basic protein extractable from human brain (Caspary and Field, 1965). They are sensitized to an even greater degree to a similar protein which can be isolated from neoplastic tissue-cancer basic protein (Ca.B.P.) (Field and Caspary, 1970; Caspary and Field, 1971)and the reverse is true in patients with organic nervous disease, where lymphocyte sensitization to E.F. is in general greater than to Ca.B.P. A comparison has now been made with sensitization to carcinoembryonic antigen (C.E.A.; Gold and Freedman, 1965), which is extractable from cancer of the colon tissue and from fetal gut and has been claimed to be an antigen characteristic of human tumours. Since C.E.A. is in strictly limited supply this preliminary report is limited in scale but makes it clear that lymphocytes are sensitized to C.E.A. in a number of conditions including, rather unexpectedly, multiple sclerosis.

\section{Materials and Methods}

Blood lymphocytes were isolated from 10-15 $\mathrm{ml}$ of venous blood by the method of Coulson and Chalmers (1967) as modified by Hughes and Caspary (1970) using carbonyl iron and methylcellulose. Six normal subjects, 11 pregnant and puerperal women, 5 cancer patients, 10 multiple sclerosis patients ( 3 active, 7 quiescent), 12 patients with other neurological diseases (stroke, syringomyelia, encephalitis, etc.), and 6 patients with general paralysis of the insane (G.P.I.) were studied.

\footnotetext{
Medical Research Council Demyelinating Diseases Unit, Newcastle
} General Hospital, Newcastle upon Tyne

E. J. FIELD, M.D., M.S., Professor of Experimental Neuropathology E. A. CASPARY, M.SC., Member of Scientific Staff
Cellular sensitization was measured by the macrophage electrophoretic migration method described by Field and Caspary (1970) and Caspary and Field (1971). In principle the method depends on the interaction of sensitized lymphocytes with antigen to liberate some material (involving protein synthesis (Caspary, 1971, 1972)) with the property of causing normal guinea-pig macrophages to travel more slowly in an electric field. The liberated material (macrophage slowing factor) may well be the same as macrophage inhibitory factor, which forms the basis of the widely recognized macrophage migration inhibition test (David et al., 1964) for delayed hypersensitivity (Bloom and Bennett, 1966).

In practice normal guinea-pig macrophages are raised by intraperitoneal inoculation of sterile liquid paraffin and removal of the cellular exudate 6-10 days later with heparinized Hanks's balanced salt solution. Since the $10-20 \%$ of lymphocytes which are present in the exudate may enter into a mixed lymphocyte reaction with human lymphocytes, the exudate is exposed to 100 rads of gamma-irradiation, which incapacitates (at least temporarily) normal non-sensitized guinea-pig lymphocytes from entering into a mixed reaction, so that only the one-way human versus guinea-pig remains and is taken into consideration in the control measurements. In carrying out an experiment, $0.5 \times 10^{6}$ of the lymphocytes to be tested were mixed with $10^{7}$ irradiated guinea-pig macrophages in $3.0 \mathrm{ml}$ of medium 199. This mixture constituted the control tube. Antigens were added in $0.1 \mathrm{ml}$ of medium 199 or saline to other tubes. The mixtures were incubated for 90 minutes at $20^{\circ} \mathrm{C}$ (room temperature) before macrophage migration time was measured.

In the present experiments C.E.A. was used in concentrations of $33 \mu \mathrm{g} / \mathrm{ml}$, so that $100 \mu \mathrm{g}$ was incorporated in $3.0 \mathrm{ml}$, the standard antigen concentration throughout the series of experiments. Although the antigen was not clear of a small amount of muco-polysaccharides it gave clear-cut reactions. Cancer antigen was the basic protein (Ca.B.P.) prepared by Dr. J. P. Dickinson from a cancer of the cervix according to the method of Caspary and Field (1971). All measurements were made "blind" in a Zeiss cell electrophoresis apparatus (cytopherometer). A detailed account of the experimental method with an original protocol in extenso was given by Caspary and Field (1971).

If $t_{c}=$ migration time of macrophages without antigen present, and $t_{c}=$ time when antigen is present, then if a macrophage slowing factor has been produced

$$
t_{e}>t_{c} \text { and } \frac{t_{c}-t_{c}}{t_{c}} \times 100
$$

is a measure of macrophage sensitization. It represents the percentage increase in migration time resulting from the macrophage slowing factor produced by antigen-lymphocytes interaction, and these percentage figures are those given in Tables I-VII. Each $t_{c}$ and $t_{c}$ value was calculated from the mean of 20 